\title{
Bio-transformation of FXR antagonist CDRI 80/574 ${ }^{1}$
}

\author{
Alok K. Verma, Priti Khemaria, Jyoti Gupta, Dharmendra P. Singh, Bhawani S. Joshi, \\ Raja Roy, Anjani K. Mishra, and Ram Pratap* \\ Division of Medicinal \& Process Chemistry, Division of Fermentation Technology and \\ Sophisticated Analytical Instrumentation Facility, Central Drug Research Institute (CSIR), \\ Lucknow-226001, India \\ E-mail: r_pratap@cdri.res.in
}

\begin{abstract}
The bio-transformation of 3- $\beta$-hydroxy-5, 16-dien-pregnane-20-one (CDRI 80/574, 1) a novel antagonist of farnesoid $\mathrm{X}$ receptor (FXR) on hepatic membranes, with Aspergillus niger produced the oxidation products at $\mathrm{C}_{3}$ and / or $\mathrm{C}_{11}$ (compound 2 and 3) while the Aspergillus ochraeus promoted the oxidation at $\mathrm{C}_{11}$ and / or $\mathrm{C}_{15}$ (compound 4 and 5). The products were characterized using 2D-NMR spectroscopy.
\end{abstract}

Keywords: 3 3-Hydroxy-5, 16-dien-pregnane-20-one, bio-transformation, FXR receptor, Aspergillus niger

\section{Introduction}

Bile consists of bile acids (BAs), cholesterol, phosphatidylcholine, and bilirubin, and is secreted from the hepatocytes into the bile canaliculi. The amphipathic properties of bile acids promote the solubilization and subsequent absorption of dietary lipids in the digestive tract. ${ }^{1}$ Besides their well-established roles in dietary lipid absorption and cholesterol homeostasis, BAs also act as signaling molecules with systemic endocrine functions. BAs activate mitogen-activated protein kinase (MAPK) pathways ${ }^{2}$, nuclear hormone receptors such as farnesoid X receptor- $\alpha^{3}$ (FXR) and are also ligands for the G-protein-coupled receptor TGR $5^{4}$. Through activation of these diverse signaling pathways, BAs can regulate their own enterohepatic circulation and also triglyceride, cholesterol, energy, and glucose homeostasis. A major physiological role of FXR is to protect liver cells from the deleterious effects of BA overload by decreasing the endogenous production of BAs and by accelerating BA bio-transformation and excretion, thereby acting as an intracellular BA sensor. ${ }^{5}$ 3 $\beta$-Hydroxy-5, 16-dien-pregnane-20-one (CDRI/80-574), a close

\footnotetext{
${ }^{1}$ CDRI Communication No. 7614.
} 
analogue of Guggulsterone has been demonstrated to be a novel FXR antagonist being devoid of the pharmacophoric groups of cholic, deoxycholic or chenodeoxycholic acids. The molecule has exhibited significant triglycerides, cholesterol, phospholipids and LDL cholesterol lowering activities in various animal models ${ }^{6}$. Guggulsterone and CDRI/80-574 are the only compounds of pregnane class which lower lipid profile through antagonism of FXR receptor and have generated interest world over ${ }^{7}$. CDRI/80-574 has successfully completed phase III human trial. In the process of drug development, there comes a stage of assessing the oral bio-availability of the candidate drug after confirmation of its biological efficacy through screening in various animal models, to modulate its safe dose for optimum activity. Oral bio-availability of a drug candidate can be measured either through the analysis of parent molecule or its metabolites. The metabolites of the candidate drug are also required to establish its efficacy and safety. The biotransformation of a drug is considered as a detoxification reaction, leading to the formation of more polar substances which are more easily eliminated from the biological system. However in some cases, this metabolism can lead to activation, producing either pharmacologically more active substances or toxic reactive metabolites.

One way of finding the drug in plasma is through radio-tracer tagged onto the intact molecule or through the identification of possible metabolites by comparison with the standard samples. These possible standard metabolites are to be prepared either via microbial route or chemical synthesis. The oxidative reactions in animals involve various types of reactions essentially catalyzed by monoamine oxidases and flavine or cytochrome P-450 mono-oxygenases. The microbial hydroxylation of steroids and subsequently preparation of corticosteroids on industrial scale demonstrated that mono-oxygenase enzymes were present in microorganisms and proved to be mechanistically similar to mammalian hepatic mono-oxygenases. The systematic examination of microbial hydroxylation on a variety of model aromatic compounds and O- and $\mathrm{N}$-dealkylation reactions, led Smith and $\operatorname{Rosazza}^{8}$ to propose that the microbial transformation system could closely mimic most of transformation reactions of drugs observed in mammals. This therefore led us to study microbial bio-transformation of 3 $\beta$-hydroxy-5, 16-dien-pregnane20-one (CDRI/80-574, 1) and report here the isolation and characterization of the biotransformation products 2-5 by two fungal strains of Aspergillus viz. Aspergillus ochraeus and Aspergillus niger (Figure 1).

\section{Results and Discussion}

The two fungal species Aspergillus ochraeus and Aspergillus niger, were utilized for regioselective oxidation of $3 \beta$-hydroxy-5, 16-dien-pregnane-20-one (1). The $\mathrm{C}_{11}$ hydroxylation was found to be the most prevalent with both the organisms. Double bond at $\mathrm{C}_{16}$ seems to play a decisive role in bringing above regioselectivity. In pregnenolone ${ }^{9}$ where $\mathrm{C}_{16}$ double is absent, no hydroxylation products at $\mathrm{C}_{11}$ were obtained while with progesterone ${ }^{10}$ hydroxylation occurred at $\mathrm{C}_{12}$ position instead of $\mathrm{C}_{11}$ on incubation with fungal strains. 
The metabolites 2-5 were characterized using FT-IR, mass and ${ }^{1} \mathrm{H},{ }^{13} \mathrm{C} \& 2 \mathrm{D}-\mathrm{NMR}$ spectral analysis.

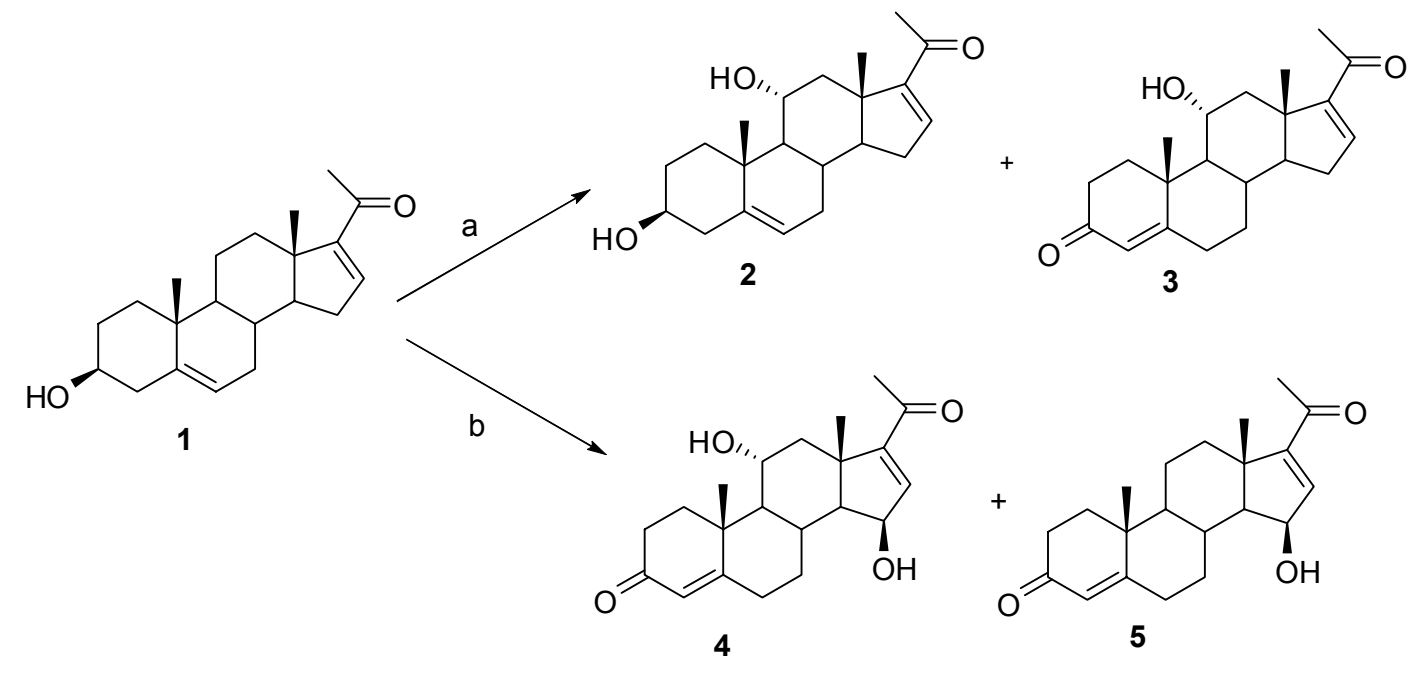

$a=A$ spergillus ochraeus, $b=$ Aspergillus niger

Figure 1. Bio-transformations of the compound 80/574, 1.

\section{3-Hydroxy-5, 16-dien-pregnane-20-one (CDRI/80-574, 1)}

16-Dehydro-pregnenolone obtained from diosgenin is commonly utilized for the synthesis of steroidal hormones. Its spectral characteristics are well established. ${ }^{11}$ In order to ascertain the structure of the metabolites, it was required to assign the chemical shifts of the parent molecule 1 itself by $1 \mathrm{D}$ and $2 \mathrm{D}$ NMR spectroscopy. In ${ }^{1} \mathrm{H} \mathrm{NMR}$, the two olefinic protons appeared at $\mathrm{C}_{6}, \mathrm{C}_{16}$ and one methine proton appeared distinctly at $\mathrm{C}_{3}$ along with three methyl signals of $\mathrm{C}_{18}, \mathrm{C}_{19}$ and $\mathrm{C}_{21}$. The proton at $\mathrm{C}_{3}$ appeared as multiplet at $\delta 3.52$. The two olefinic protons at $\mathrm{C}_{6}$ and $\mathrm{C}_{16}$ appear at $\delta 5.35$ and 6.71 respectively. The most deshielded proton at $\delta 6.71$ corresponds to $\mathrm{C}_{16}$. In DEPT-90, the six methine carbons appeared at $\delta 144.5\left(\mathrm{C}_{16}\right), 121\left(\mathrm{C}_{6}\right), 71.7\left(\mathrm{C}_{3}\right), 56.4\left(\mathrm{C}_{14}\right)$, $50.4\left(\mathrm{C}_{9}\right)$ and $30.2\left(\mathrm{C}_{8}\right)$ while seven methylene carbons appear at $\delta 42.2\left(\mathrm{C}_{4}\right), 37.1\left(\mathrm{C}_{1}\right), 34.6$ $\left(\mathrm{C}_{12}\right), 31.5\left(\mathrm{C}_{2} \& \mathrm{C}_{7}\right)$ and $20.7\left(\mathrm{C}_{11}\right)$. The chemical shifts of various protons and carbons were established using COSY, DEPT, HSQC and HMBC experiments and are given in tables 1 and 2. 
Table 1. ${ }^{1} \mathrm{H}-\mathrm{NMR}$ chemical shifts of compound CDRI 80/574 1 and metabolites 2-5

\begin{tabular}{|c|c|c|c|c|c|c|c|c|c|c|}
\hline${ }^{1} \mathrm{H}$ & 1 & & 2 & & 3 & & 4 & & 5 & \\
\hline & $\delta$ & $\mathrm{J}(\mathrm{Hz})$ & $\delta$ & $\mathrm{J}(\mathrm{Hz})$ & $\delta$ & $\mathrm{J}(\mathrm{Hz})$ & $\delta$ & $\mathrm{J}(\mathrm{Hz})$ & $\delta$ & $\mathrm{J}(\mathrm{Hz})$ \\
\hline 1 & 1.08 & $\mathrm{~m}^{\mathrm{e}}$ & 2.54 & $\begin{array}{c}\mathrm{td}(3.5, \\
13.6)\end{array}$ & 2.59 & $\begin{array}{c}\mathrm{td}(4.5, \\
14.0)\end{array}$ & 2.52 & $\mathrm{~m}^{\mathrm{e}}$ & 1.7 & $\mathrm{~m}^{\mathrm{e}}$ \\
\hline 1 ' & 1.85 & $\mathrm{~m}^{\mathrm{e}}$ & 1.19 & $\mathrm{~m}^{\mathrm{e}}$ & 2.09 & $\mathrm{~m}^{\mathrm{e}}$ & 2.09 & $\mathrm{~m}^{\mathrm{e}}$ & 2.07 & $\mathrm{~m}^{\mathrm{e}}$ \\
\hline 2 & 1.84 & $\mathrm{~m}^{\mathrm{e}}$ & 1.82 & $\mathrm{~m}^{\mathrm{e}}$ & 2.43 & $\mathrm{~m}^{\mathrm{e}}$ & 2.44 & $\mathrm{~m}^{\mathrm{e}}$ & 2.49 & $\mathrm{~m}^{\mathrm{e}}$ \\
\hline 2 ' & 1.5 & $\mathrm{~m}^{\mathrm{e}}$ & 1.54 & $\mathrm{~m}^{\mathrm{e}}$ & 2.34 & $\mathrm{~m}^{\mathrm{e}}$ & 2.27 & $\mathrm{~m}^{\mathrm{e}}$ & 2.29 & $\mathrm{~m}^{\mathrm{e}}$ \\
\hline 3 & 3.52 & $\mathrm{~m}^{\mathrm{e}}$ & 3.53 & $\mathrm{~m}^{\mathrm{e}}$ & - & & - & - & - & - \\
\hline 4 & 2.27 & $\mathrm{~m}^{\mathrm{e}}$ & 2.29 & $\mathrm{~m}^{\mathrm{e}}$ & 5.74 & brs & 5.73 & brs & 5.72 & brs \\
\hline 5 & - & - & - & - & - & - & - & - & - & - \\
\hline 6 & 5.36 & $\mathrm{~d}(5.6)$ & 5.43 & $d(5.6)$ & 2.44 & $\mathrm{~m}^{\mathrm{e}}$ & 2.56 & $\mathrm{~m}^{\mathrm{e}}$ & 2.58 & $\begin{array}{c}\text { ddd }(1.8,5.3 \text {, } \\
14.7)\end{array}$ \\
\hline 6 ' & - & - & - & - & 2.34 & $\mathrm{~m}^{\mathrm{e}}$ & 2.36 & $\begin{array}{c}\mathrm{ddd} \\
(14.6,2.5,3.9)\end{array}$ & 2.35 & $\begin{array}{c}\mathrm{ddd} \\
(2.6,4.1,14.7)\end{array}$ \\
\hline 7 & 1.99 & $\mathrm{~m}^{\mathrm{e}}$ & 2.02 & $\mathrm{~m}^{\mathrm{e}}$ & 1.88 & $\mathrm{~m}^{\mathrm{e}}$ & 2.24 & $\mathrm{~m}^{\mathrm{e}}$ & 2.21 & $\mathrm{~m}^{\mathrm{e}}$ \\
\hline 7 ' & 1.6 & $\mathrm{~m}^{\mathrm{e}}$ & 1.7 & $\mathrm{~m}^{\mathrm{e}}$ & 1.18 & $\mathrm{~m}^{\mathrm{e}}$ & 1.21 & $\mathrm{~m}^{\mathrm{e}}$ & 1.19 & $\mathrm{~m}^{\mathrm{e}}$ \\
\hline 8 & 1.7 & $\mathrm{~m}^{\mathrm{e}}$ & 1.65 & $\mathrm{~m}^{\mathrm{e}}$ & 1.78 & $\begin{array}{c}\mathrm{qd}(3.1, \\
11.5)\end{array}$ & 2.05 & $\mathrm{~m}^{\mathrm{e}}$ & 2.05 & $\mathrm{~m}^{\mathrm{e}}$ \\
\hline 9 & 1.01 & $\mathrm{~m}^{\mathrm{e}}$ & 1.08 & $\mathrm{t}(9.8)$ & 1.19 & - & 1.20 & $\mathrm{~m}^{\mathrm{e}}$ & 1.08 & $\mathrm{~m}^{\mathrm{e}}$ \\
\hline 10 & - & - & - & - & - & - & - & & - & - \\
\hline 11 & 1.59 & $\mathrm{~m}^{\mathrm{e}}$ & 4.18 & $\begin{array}{c}\operatorname{td}(5.7 \\
10.3)\end{array}$ & 4.14 & $\begin{array}{c}\operatorname{td}(5.4 \\
10.3)\end{array}$ & 4.09 & $\operatorname{td}(5.5,10.0)$ & 1.63 & $\mathrm{~m}^{\mathrm{e}}$ \\
\hline $11^{\prime}$ & 1.34 & $\mathrm{~m}^{\mathrm{e}}$ & - & - & - & - & 2.59 & $\mathrm{~m}^{\mathrm{e}}$ & - & - \\
\hline 12 & 2.4 & $\begin{array}{c}\operatorname{td}(3.1, \\
12.8)\end{array}$ & 2.78 & $\begin{array}{c}\mathrm{dd}(5.5, \\
11.9)\end{array}$ & 2.8 & $\begin{array}{c}\mathrm{dd}(5.5 \\
12.1)\end{array}$ & 1.29 & $\mathrm{~m}^{\mathrm{e}}$ & 2.27 & $\mathrm{~m}^{\mathrm{e}}$ \\
\hline $12^{\prime}$ & 1.34 & $\mathrm{~m}^{\mathrm{e}}$ & 1.38 & $\mathrm{t}(11.3)$ & 1.40 & $\mathrm{~m}^{\mathrm{e}}$ & - & & 1.27 & $\mathrm{~m}^{\mathrm{e}}$ \\
\hline 13 & - & - & - & - & - & - & - & - & - & - \\
\hline 14 & 1.42 & $\mathrm{~m}^{\mathrm{e}}$ & 1.55 & $\mathrm{~m}^{\mathrm{e}}$ & 1.57 & $\begin{array}{c}\operatorname{td}(6.4, \\
11.7)\end{array}$ & 1.39 & - & 1.28 & $\mathrm{~m}^{\mathrm{e}}$ \\
\hline 15 & 2.32 & $\mathrm{~m}^{\mathrm{e}}$ & 2.33 & $\mathrm{~m}^{\mathrm{e}}$ & 2.35 & $\begin{array}{c}\mathrm{dd}(2.9, \\
5.3)\end{array}$ & 4.62 & $\mathrm{dd}(2.9,5.3)$ & 4.61 & $\mathrm{dd}(2.9,5.3)$ \\
\hline $15^{\prime}$ & 2.05 & $\mathrm{~m}^{\mathrm{e}}$ & 2.05 & $\mathrm{~m}^{\mathrm{e}}$ & 2.08 & $\mathrm{~m}^{\mathrm{e}}$ & - & - & - & - \\
\hline 16 & 6.72 & $\begin{array}{c}\mathrm{dd} \\
(1.8,3.2)\end{array}$ & 6.72 & $\begin{array}{c}\mathrm{dd} \\
(1.8,3.2)\end{array}$ & 6.72 & $\begin{array}{c}\mathrm{dd}(1.8, \\
3.2)\end{array}$ & 6.86 & $\mathrm{~d}(2.9)$ & 6.8 & $\mathrm{~d}(2.9)$ \\
\hline 17 & - & - & - & - & - & - & - & - & - & - \\
\hline 18 & 0.92 & $\mathrm{~s}$ & 0.93 & $\mathrm{~s}$ & 0.95 & $\mathrm{~s}$ & 1.24 & $\mathrm{~s}$ & 1.25 & $\mathrm{~s}$ \\
\hline 19 & 1.04 & $\mathrm{~s}$ & 1.19 & $\mathrm{~s}$ & 1.34 & $\mathrm{~s}$ & 1.39 & $\mathrm{~s}$ & 1.29 & $\mathrm{~s}$ \\
\hline 20 & - & - & - & - & - & - & - & - & - & - \\
\hline 21 & 2.26 & $\mathrm{~s}$ & 2.26 & $\mathrm{~s}$ & 2.27 & $\mathrm{~s}$ & 2.29 & $\mathrm{~s}$ & 2.30 & $\mathrm{~s}$ \\
\hline
\end{tabular}

$\mathrm{m}^{\mathrm{e}}$ : multiplet overlapped with other signals, $\mathrm{s}$ : singlet, brs: broad singlet, d: doublet, td: triplet of a doublet, $\mathrm{dd}$ : doublet of a doublet, $\mathrm{qd}=$ quartet of a doublet, $\mathrm{ddd}=\mathrm{doublet}$ of a doublet of a doublet. 
Table 2. ${ }^{13} \mathrm{C}$-NMR chemical shifts of compound CDRI 80/574 and metabolites

\begin{tabular}{|c|c|c|c|c|c|c|c|c|c|c|}
\hline${ }^{13} \mathrm{C}$ & 1 & & 2 & & 3 & & 4 & & 5 & \\
\hline & $\delta$ & $\begin{array}{l}\text { Type of } \\
\text { carbon }\end{array}$ & $\delta$ & $\begin{array}{l}\text { Type of } \\
\text { carbon }\end{array}$ & $\delta$ & $\begin{array}{l}\text { Type of } \\
\text { carbon }\end{array}$ & $\delta$ & $\begin{array}{l}\text { Type of } \\
\text { carbon }\end{array}$ & $\delta$ & $\begin{array}{l}\text { Type of } \\
\text { carbon }\end{array}$ \\
\hline 1 & 37.1 & $\mathrm{CH}_{2}$ & 38.9 & $\mathrm{CH}_{2}$ & 37.1 & $\mathrm{CH}_{2}$ & 38.2 & $\mathrm{CH}_{2}$ & 36.7 & $\mathrm{CH}_{2}$ \\
\hline 2 & 31.5 & $\mathrm{CH}_{2}$ & 31.7 & $\mathrm{CH}_{2}$ & 34.1 & $\mathrm{CH}_{2}$ & 35 & $\mathrm{CH}_{2}$ & 34.8 & $\mathrm{CH}_{2}$ \\
\hline 3 & 71.7 & $\mathrm{CH}$ & 71.8 & $\mathrm{CH}$ & 200.3 & $\mathrm{C}$ & 202.9 & $\mathrm{CH}$ & 202.4 & $\mathrm{CH}$ \\
\hline 4 & 42.2 & $\mathrm{CH}_{2}$ & 42.7 & $\mathrm{CH}_{2}$ & 124.5 & $\mathrm{CH}$ & 124.7 & $\mathrm{CH}_{2}$ & 124.3 & $\mathrm{CH}_{2}$ \\
\hline 5 & 141.4 & $\mathrm{C}$ & 141.8 & $\mathrm{C}$ & 170.9 & $\mathrm{C}$ & 175.2 & $\mathrm{C}$ & 175.2 & $\mathrm{C}$ \\
\hline 6 & 121 & $\mathrm{CH}$ & 120.9 & $\mathrm{CH}$ & 33.3 & $\mathrm{CH}_{2}$ & 34.6 & $\mathrm{CH}$ & 33.9 & $\mathrm{CH}_{2}$ \\
\hline 7 & 31.5 & $\mathrm{CH}_{2}$ & 31.7 & $\mathrm{CH}_{2}$ & 31.6 & $\mathrm{CH}_{2}$ & 32.1 & $\mathrm{CH}_{2}$ & 32.3 & $\mathrm{CH}_{2}$ \\
\hline 8 & 30.2 & $\mathrm{CH}$ & 30.3 & $\mathrm{CH}$ & 33.4 & $\mathrm{CH}$ & 32.2 & $\mathrm{CH}$ & 32.4 & $\mathrm{CH}$ \\
\hline 9 & 50.4 & $\mathrm{CH}$ & 57.3 & $\mathrm{CH}$ & 59.3 & $\mathrm{CH}$ & 61.0 & $\mathrm{CH}$ & 56.1 & $\mathrm{C}$ \\
\hline 10 & 36.6 & $\mathrm{C}$ & 38.3 & $\mathrm{C}$ & 40.0 & $\mathrm{C}$ & 41.8 & $\mathrm{C}$ & 40.3 & $\mathrm{CH}_{2}$ \\
\hline 11 & 20.7 & $\mathrm{CH}_{2}$ & 68.7 & $\mathrm{CH}_{2}$ & 68.4 & $\mathrm{CH}$ & 68.7 & $\mathrm{CH}_{2}$ & 21.7 & $\mathrm{CH}_{2}$ \\
\hline 12 & 34.6 & $\mathrm{CH}_{2}$ & 46.1 & $\mathrm{CH}_{2}$ & 46.3 & $\mathrm{CH}_{2}$ & 47.3 & $\mathrm{CH}_{2}$ & 36.0 & $\mathrm{CH}_{2}$ \\
\hline 13 & 46.0 & $\mathrm{C}$ & 46.3 & $\mathrm{C}$ & 46.2 & $\mathrm{C}$ & 47.9 & $\mathrm{C}$ & 47.9 & $\mathrm{C}$ \\
\hline 14 & 56.4 & $\mathrm{CH}$ & 55.5 & $\mathrm{CH}$ & 54.9 & $\mathrm{CH}$ & 59.0 & $\mathrm{CH}$ & 60.0 & $\mathrm{CH}$ \\
\hline 15 & 32.2 & $\mathrm{CH}_{2}$ & 32.1 & $\mathrm{CH}_{2}$ & 31.9 & $\mathrm{CH}_{2}$ & 73.0 & $\mathrm{CH}_{2}$ & 73.2 & $\mathrm{CH}_{2}$ \\
\hline 16 & 144.5 & $\mathrm{CH}$ & 144.6 & $\mathrm{CH}$ & 144.5 & $\mathrm{CH}$ & 145.3 & $\mathrm{CH}$ & 144.9 & $\mathrm{CH}$ \\
\hline 17 & 155.3 & $\mathrm{C}$ & 154.6 & $\mathrm{C}$ & 154.4 & $\mathrm{C}$ & 157.3 & $\mathrm{C}$ & 157.9 & $\mathrm{C}$ \\
\hline 18 & 15.7 & $\mathrm{CH}_{3}$ & 16.9 & $\mathrm{CH}_{3}$ & 17.1 & $\mathrm{CH}_{3}$ & 23.5 & $\mathrm{CH}_{3}$ & 22.4 & $\mathrm{CH}_{3}$ \\
\hline 19 & 19.3 & $\mathrm{CH}_{3}$ & 19.2 & $\mathrm{CH}_{3}$ & 18.3 & $\mathrm{CH}_{3}$ & 18.8 & $\mathrm{CH}_{3}$ & 17.5 & $\mathrm{CH}_{3}$ \\
\hline 20 & 196.9 & $\mathrm{C}$ & 196.6 & $\mathrm{C}$ & 196.5 & $\mathrm{C}$ & 199.7 & $\mathrm{C}$ & 200.0 & $\mathrm{C}$ \\
\hline 21 & 27.1 & $\mathrm{CH}_{3}$ & 26.9 & $\mathrm{CH}_{3}$ & 26.9 & $\mathrm{CH}_{3}$ & 27.5 & $\mathrm{CH}_{3}$ & 27.6 & $\mathrm{CH}_{3}$ \\
\hline
\end{tabular}

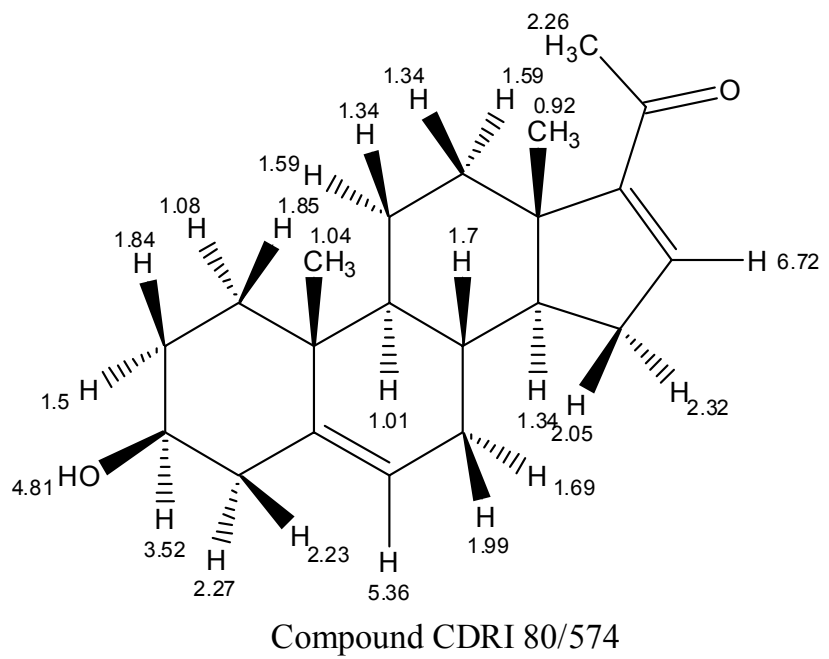




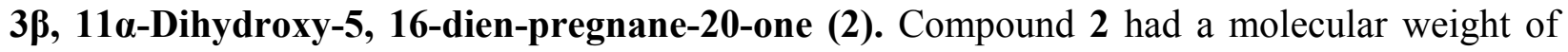
$330 \mathrm{~m} / \mathrm{e}$ an increment of $16 \mathrm{~m} / \mathrm{e}$ unit from parent molecule. This clearly indicates an introduction of hydroxyl functionality in the molecule. In ${ }^{1} \mathrm{H}$ NMR, there appeared an additional multiplet at $4.18 \mathrm{ppm}$ corresponding to the proton attached with carbon having oxygen functionality. The two olefinic protons appeared at $\delta 5.43$ and 6.72 as in compound $\mathbf{1}$, which indicates that the hydroxylation has not occurred at the allylic positions. The assignments of hydrogen and carbon signals are given in table I and II respectively. As compared with parent compound $\mathbf{1}$ there is a significant difference in chemical shift of protons at $\mathrm{C}_{1}, \mathrm{C}_{11}$ and $\mathrm{C}_{12}$ and also of the carbons at $\mathrm{C}_{9}$, $\mathrm{C}_{10}, \mathrm{C}_{11}$ and $\mathrm{C}_{12}$ indicating the substitution at $\mathrm{C}_{11}$. One proton at $\mathrm{C}_{1}$ showed significant difference in the chemical shift because of its proximity to 11-hydroxyl functional group as suggested by the three dimensional structure of the compound. The two oxymethine protons (at $\mathrm{C}_{3}$ and $\mathrm{C}_{11}$ ) appeared at $\delta 3.52$ and 4.18 respectively showing HSQC correlations with oxymethine carbons at $\delta 71.6$ and 68.7 respectively. The oxymethine proton at $4.18 \mathrm{ppm}$ showed HMBC correlations with the signals of $\mathrm{C}_{10}$ at $38.3, \mathrm{C}_{13}$ at 46.3 and $\mathrm{C}_{9}$ at $57.3 \mathrm{ppm}$. The relative stereochemistry of $\mathrm{C}_{11}$ hydroxyl group is found to be $\alpha$, which is evident from NOE correlations.

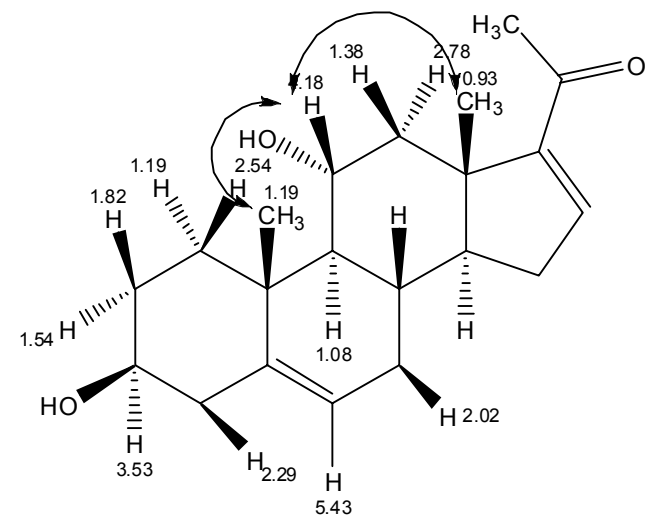

Selected NOESY correlations in compound 2

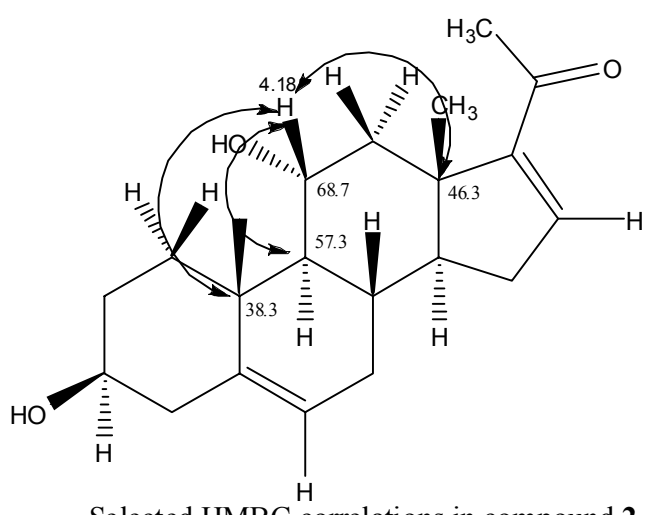

Selected HMBC correlations in compound 2

In NOESY, the oxymethine proton $\left(\mathrm{C}_{11} \mathrm{H}\right)$ signal at $\delta 4.18$ showed correlations with $\beta$-methyl protons at $\mathrm{C}_{18}$ and $\mathrm{C}_{19}$ as evident from their proximity in three-dimensional structure.

11a-Hydroxy-4, 16-dien-pregnan-3, 20-dione (3). The ${ }^{13} \mathrm{C}$ NMR spectrum of compound 3 provided twenty one signals which include three methyls, six methylenes, six methines and six quaternary carbons. Among quaternary carbons an additional carbonyl carbon at $\delta 200.3$ was observed instead of an aliphatic methylene carbon as evaluated from the DEPT edited spectra. The olefinic proton of compound 1 at $\delta 5.36$ showed a downfield shift and appeared at $\delta 5.74$ for compound 3. On analysis of the ${ }^{1} \mathrm{H}$ NMR spectrum it was observed that the olefinic proton at $\delta$ 5.74 appeared as a broad singlet and showed COSY correlation with the proton at $\delta 2.43$. One of the methylene protons showed correlation with the carbon at $\delta 34.1$ in the HSQC spectrum. This olefinic proton provided a long range correlation with the same carbon (at $\delta 34.1$ ) in the HMBC spectrum. Moreover, the $\mathrm{C}_{19}$ methyl proton provided long range correlation with the $\mathrm{C}_{1}$ 
methylene carbon at $\delta 37.1$. The corresponding $\mathrm{C}_{1}$ protons at $\delta 2.59$ and 2.09 showed long range correlations with the carbonyl carbon at $\delta$ 200.3. Other than the two long range correlations of $\mathrm{C}_{1}$ protons with the carbonyl carbon at $\delta 200.3$, two more long range correlations of protons at $\delta$ 2.43 and 2.34 were observed with of the methylene carbon at $\delta 34.1$. This pattern of correlations can only be obtained when the carbonyl is at $\mathrm{C}_{3}$ and the double bond is between $\mathrm{C}_{4}$ and $\mathrm{C}_{5}$. It was further reinstated by the down field shift $(\sim 29.5 \mathrm{ppm})$ of $\mathrm{C}_{5}$ at $\delta 170.9$ with respect to the compound 1 due to the conjugation in 3 . The confirmation of $\mathrm{C}_{5}$ chemical shift was carried out on the basis of long range correlations of $\mathrm{C}_{19}$ methyl with $\mathrm{C}_{5}$ respectively. The position of the hydroxyl group at $\mathrm{C}_{11}$ was confirmed on the basis of distinct multiplicity, correlations in the COSY spectrum as well as the long-range correlations in the HMBC spectrum. The NOESY correlations of $\mathrm{C}_{11}$ with $\mathrm{C}_{18}$ methyl and $\mathrm{C}_{19}$ methyl further confirmed the hydroxyl group to be $\alpha$ in nature. The detailed ${ }^{1} \mathrm{H}$ and ${ }^{13} \mathrm{C}$ assignments are presented in tables I and II.

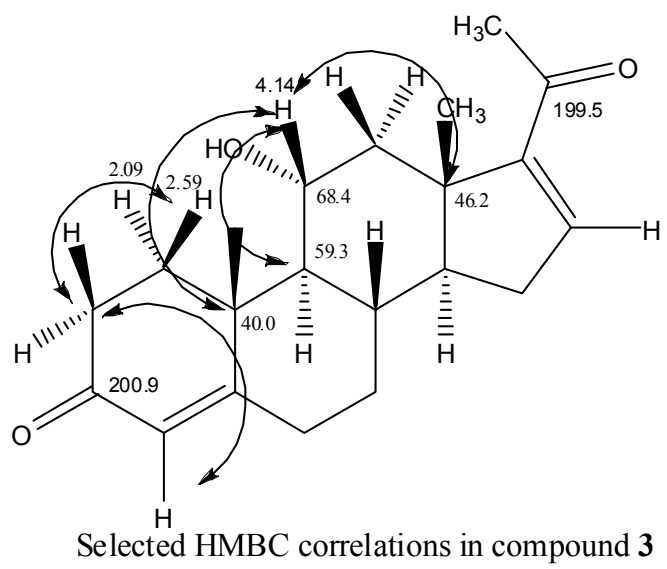

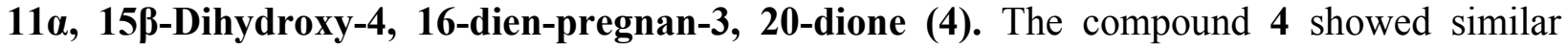
spectral features as of compound 3 with an additional hydroxyl group. In ${ }^{13} \mathrm{C}$ spectrum, there appeared two signals of carbonyl carbons at $\delta 202.9$ and 199.7 and the signal at $\delta 202.9$ showed HMBC correlations similar to compound 3, this suggest that the carbonyl is at $\mathrm{C}_{3}$. The two methine signals attached with oxygen appeared at $\delta 4.09$ and 4.62. The down field shift of one of these protons indicates its allylic position. The position of the hydroxyl group at $\mathrm{C}_{15}$ was confirmed on the basis of the COSY spectrum as it showed correlations with the protons at $\delta$ 6.86 (olefinic proton, $\left.\mathrm{H}_{16}\right)$ and $\delta 1.39 \mathrm{ppm}\left(\mathrm{H}_{14}\right)$. It was further reconfirmed by the HMBC correlations. The relative stereochemistry of the hydroxyl group was confirmed by the coupling constant of $5.3 \mathrm{~Hz}$ between $\mathrm{H}_{14}$ and $\mathrm{H}_{15}$. The detailed assignments are given in tables I and II. 


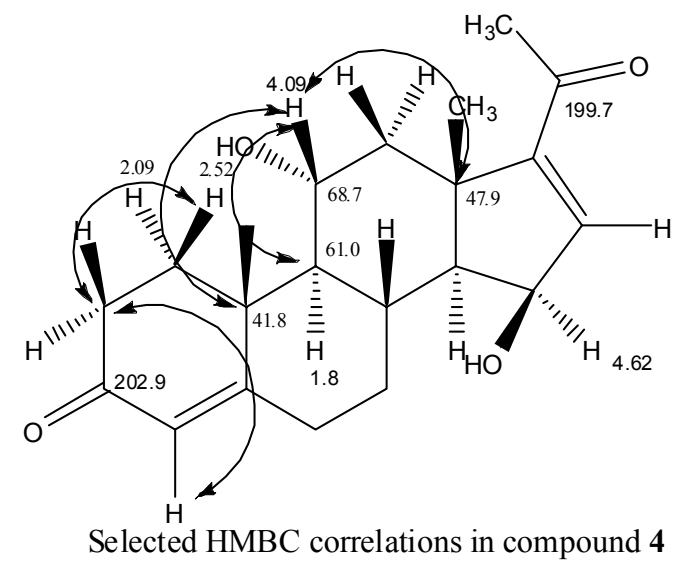

15ß-Hydroxy-4, 16-dien-pregnan-3, 20-dione (5). The spectral pattern of compound 5 shows similar profile in comparison to compound 4 except the absence of $\mathrm{C}_{11}$ hydroxyl group. Carbonyl carbon at $\delta 202.4$ showed $\mathrm{HMBC}$ correlations with protons at $\delta 1.7,2.07,2.49$ and 2.29 corresponding to $\mathrm{C}_{1}, \mathrm{C}_{1}$, and $\mathrm{C}_{2}$, protons. Similarly carbon at $\delta 73.23$ showed HSQC correlation with $\mathrm{C}_{15}$ proton $(\delta 4.62)$ and $\mathrm{HMBC}$ correlations with $\mathrm{C}_{14}$ and $\mathrm{C}_{16}$ protons $(\delta 1.28$ and 6.80$)$. The relative stereochemistry of the hydroxyl group was confirmed by the coupling constant of $5.3 \mathrm{~Hz}$ between $\mathrm{H}_{14}$ and $\mathrm{H}_{15}$.

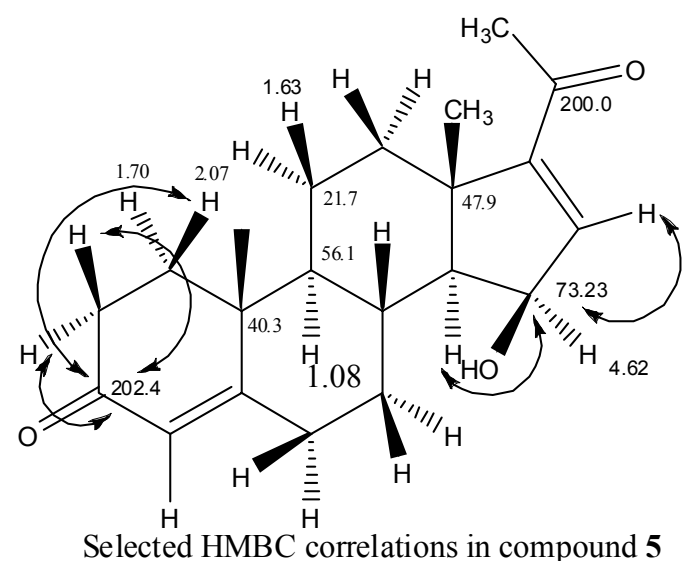

Compound 2 and 3 have earlier been prepared either from 11-hydroxy-progesterone, 11-oxo-16dehydropregnenolone or 11-hydroxy-diosgenin following chemical route ${ }^{12,13}$ or via biotransformation with Aspergillus ochraeus ${ }^{14}$. In above methods, 11-hydroxy-progesterone has been prepared from 11-hydroxy-diosgenin. The compound $\mathbf{4}$ is novel and has not been reported so far whereas compound $\mathbf{5}$ has been reported as microbial biotransformation product of 16dehydroprogesterone by a fungus Absidia orchidis ${ }^{15}$. 


\section{Conclusion}

3- $\beta$-Hydroxy-5, 16-dien-pregnane-20-one (1), when subjected to microbial conversion with two fungal species of Aspergillus leads to the formation of regioselective products being oxidized at $\mathrm{C}_{3}, \mathrm{C}_{11}$ or $\mathrm{C}_{15}$ position. Our study demonstrates a simple method of obtaining compound $\mathbf{2}$ which is the precursor for the synthesis of the most of the hormone class of compounds. We have isolated four metabolites $\mathbf{2 - 5}$ and the novel metabolite $\mathbf{4}$ has been characterized.

\section{Experimental Section}

Cultures. A fungal strain Aspergillus ochraeus and a strain of Aspergillus niger, isolated from soil samples collected from Ambikapur, Chhattisgarh (India) were used in present study. Pure cultures were isolated on Sabouraud dextrose agar plates containing antibiotic Rifampicin $(1 \mu \mathrm{g} / \mathrm{ml})$. The stock cultures were routinely maintained on Sabouraud dextrose agar slants in 6 " 11 " test tubes at $4{ }^{\circ} \mathrm{C}$.

Media. Sabouraud-dextrose agar containing glucose- $40 \mathrm{~g} / \mathrm{L}$, peptone- $10 \mathrm{~g} / \mathrm{L}$ and agar $20 \mathrm{~g} / \mathrm{L}$ was used as culture maintenance medium. Czapek Dox broth containing cane sugar $30 \mathrm{~g} / 1$, sodium nitrate $3 \mathrm{~g} / \mathrm{L}$, di-potassium hydrogen phosphate- $1 \mathrm{~g} / \mathrm{L}$, magnesium sulfate- $0.5 \mathrm{~g} / \mathrm{L}$, potassium chloride $0.5 \mathrm{~g} / \mathrm{L}$, ferrous sulfate- $10 \mathrm{mg}$ at $\mathrm{pH}-7$ in $100 \mathrm{ml} / \mathrm{L}$ Erlenmeyer flask autoclaved at 10 pounds /10 min was used as production medium.

Preparation of spores suspension. Spore suspension from 10-15 days old slant culture, was prepared in $200 \mathrm{ml}$ of sterilized distilled water (Approximate cell count was 2-6 x10 ${ }^{6}$ ).

Inoculation of production medium. In order to achieve $2-6 \times 10^{5}$ spores / flask appropriate volume of spore suspension was used to inoculate each production flask and incubated for $48 \mathrm{hrs}$ to achieve fine pellet at $28 \pm 1{ }^{\circ} \mathrm{C}$ on rotatory shaker assembly revolving at $180 \mathrm{rpm}$ with a throw of $1 \mathrm{~cm} .5 \mathrm{ml}$ of ethanol containing $25 \mathrm{mg}$ of 33-hydroxy-5, 16-dien-pregnane-20-one (1) was added in each flask to achieve $0.25 \mathrm{mg} / \mathrm{ml}$ final substrate concentration and continued the incubation for $48 \mathrm{hrs}$.

Recovery. Biomass was separated out by vacuum filtration. Filtrate was extracted twice by equal volume of chloroform and biomass (17-20 g/wet wt. and 3.4-5 g/L dry wt.) was extracted firstly by acetone followed by evaporation and re-extracted by chloroform. Combined extracts were evaporated to dryness and dried crude product was subjected to column chromatography.

General. The progress of the transformation was monitored by thin layer chromatography on Merck silica-gel $60-\mathrm{F}_{254}$ coated plates. Spots were run in acetone and benzene mixture (20:80 $\mathrm{v} / \mathrm{v}$ ) and observed under UV light. Transformed products were separated by column chromatography on silica-gel (100-200 mesh) column using benzene and ethyl acetate mixture as eluent. IR spectra were recorded on Perkin-Elmer RXI FT-IR spectrometer using KBr pellets or 
neat (expressed in $\left.\mathrm{cm}^{-1}\right) .{ }^{1} \mathrm{H}$ NMR $(400 \mathrm{MHz})$ and ${ }^{13} \mathrm{C}$ NMR $(100 \mathrm{MHz})$ were recorded in $\mathrm{CD}_{3} \mathrm{OD}$ or $\mathrm{CDCl}_{3}$ (Aldrich) as solvent on a Bruker Avance DRX-400 calibrated with TMS as internal standard. ${ }^{1} \mathrm{H}$ and ${ }^{13} \mathrm{C}$ chemical shifts of all the five compounds are given in tables 1 and 2 respectively. ES-MS was recorded in $\mathrm{CH}_{3} \mathrm{OH}$ on a Micromass Quattro II. The FAB-MS was recorded using a Jeol SX-120/DA6000 mass spectrometer using Argon as the FAB gas.

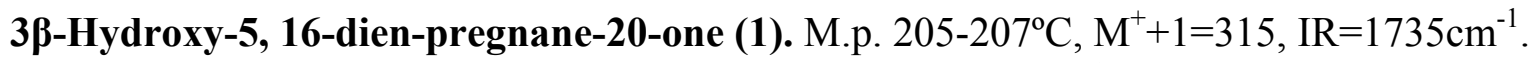

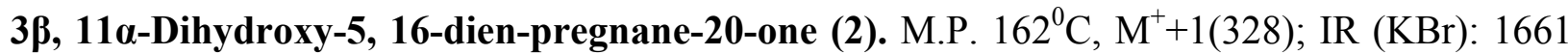
$\mathrm{cm}^{-1}$.

11a-Hydroxy-4, 16-dien-pregnan-3, 20-dione (3). M.P. 205 ${ }^{0}$; $\mathrm{M}^{+}+1(330)$; IR (KBr): 1652 $\mathrm{cm}^{-1}$.

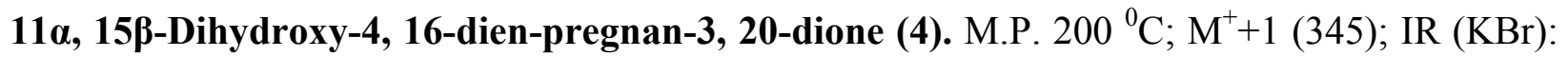
$1657 \mathrm{~cm}^{-1}$.

15ß-Hydroxy-4, 16-dien-pregnan-3, 20-dione (5). M.P. $210{ }^{0} \mathrm{C}$; $\mathrm{M}^{+}+1$ (329); IR (KBr): 1596 $\mathrm{cm}^{-1}$.

\section{Acknowledgements}

We are thankful to the Director CDRI for permission to undertake the present work. We acknowledge CSIR for fellowships to Priti, Jyoti, D. P. Singh and A. K. Verma. We also thank Mr. Malkhan Singh and A. K. Pandey of Fermentation Technology Division for their technical assistance.

\section{References}

1. Houten, S. M.; Watanabe, M.; Auwerx, J. The EMBO J. 2006, 25, 1419.

2. Gupta, S.; Stravitz, R. T.; Dent, P.; Hylemon, P. B. J. Biol. Chem. 2001, 276,15816.

3. Makishima, M.; Okamoto, A. Y.; Repa, J. J.; Tu, H.; Learned, R. M.; Luk, A.; Hull, M. V.; Lustig, K. D.; Mangelsdorf, D. J.; Shan, B. Science 1999, 284, 1362.

4. Kawamata, Y.; Fujii, R.; Hosoya, M.; Harada, M.; Yoshida, H.; Miwa, M.; Fukusumi, S.; Habata, Y.; Itoh, T.; Shintani, Y.; Hinuma; S.; Fujisawa, Y.; Fujino, M. J. Biol. Chem. 2003, 278, 9435.

5. Cariou, B.; Staels, B. Trends Pharmacol. Sci. 2007, 28, 236.

6. (a) Schwarz, M.; Lund, E. G.; Russell, D. W. Curr. Opin. Lipidol. 1998, 9, 113. (b). Pratap, R.; Gupta, R. C.; Chander, R.; Khanna, A. K.; Srivastava, A. K.; Raina, D.; Singh, S.; Srivastava, S.; Rastogi, A. K.; Asthana, O. P.; Nityanand, S.; Anand, N.; Ghatak, A.; Kapoor, N. K.; Dev, S. U S Patent 6579862 B1, 2003.

7. Wu, J.; Xia, C.; Meier, J.; Li, S.; Hu, X.; Lala, D. Mol. Endocrinol. 2002, 16,1590. 
8. (a). Smith, R. V.; Rosazza, J. P.; Arch. Biochem. Biophys. 1974, 161, 551. (b). Smith, R. V.; Rosazza, J. P. J. Pharm. Sci. 1975, 64, 1737. (c). Smith, R. V.; Rosazza, J. P. Biotech. Bioeng. 1975, 17, 785. (d) Smith, R. V.; Acozsta, D. J.; Rosazza, J. P. Adv. Biochem. Eng. 1977, 5, 69 .

9. Wilson, M. R.; Gallimore, W.A.; Reese, P. B. Steroids 1999, 64, 834.

10. Marker, M. E.; Wagner, R. B.; Ulshafer, P. R.; Wittbecker, E. L.; Goldsmith, D. P. J.; Rouf, C. H. J. Am. Chem. Soc. 1941, 69, 2167.

11. Shingate, B. B.; Hazra, B. G.; Pore, V. S.; Gonnade, R. G.; Bhadbhade, M. M. Tetrahedron 2007, 63, 5622.

12. Halpern,O.; Djerassi, C.J. Am. Chem. Soc., 1959, 81, 439.

13. Rothman, E. S.; Wall, M. E. J. Am. Chem. Soc., 1959, 81, 411.

14. Rothman, E. S.; Wall, M. E. US Patent 2971964, 1961.

15. Zhou, W.S.; Yin, Z. H. Huaxue Xuebao 1980, 38, 467; Chem. Abstr. 1981, 94, 135712. 